\title{
NOCE MROŹNE W POZNANIU I ICH CYRKULACYJNE UWARUNKOWANIA
}

\author{
ARKADIUSZ M. TOMCZYK \\ Uniwersytet im. Adama Mickiewicza w Poznaniu, \\ Wydział Nauk Geograficznych i Geologicznych, \\ ul. B. Krygowskiego 10, 61-680 Poznań
}

\begin{abstract}
The main purpose of this article was to determine the pressure situations and circulation types causing the occurrence of frosty nights in Poznań in the years 1966/67-2015/16. A night was assumed to be a frosty night with a minimum temperature below $-10^{\circ} \mathrm{C}$. The article uses the daily values of the minimum air temperature for the period of 1966-2016 for the station in Poznań. The data was provided by the Institute of Meteorology and Water Management - National Research Institute. In the analyzed years, 10 frosty nights were recorded on average every season. Conducted studies showed a decrease in their number, although these changes were not statistically significant. The average occurrence of frosty nights was associated with the presence of a high-pressure system over Central Europe, which developed within a high-pressure ridge extending over the majority of the continent. Such a pressure situation led to the advection of continental air masses from the eastern sector.
\end{abstract}

Keywords: frosty nights, atmospheric circulation, climate changes, Poznań

\section{WSTĘP}

Występowanie ekstremalnych wartości temperatury powietrza od wielu lat stanowi przedmiot licznych publikacji, spośród których większość koncentruje się na analizie występowania dni upalnych i fal upałów (Shevchenko i in. 2014; Krzyżewska 2015; Tomczyk i Bednorz 2016; Hoy i in. 2017; Półrolniczak i in. 2018; Wibig 2018). W licznych pracach analizowano także występowanie nocy gorących lub tropikalnych w wybranych regionach Polski (Matuszko i Piotrowicz 2012; Bartoszek i in. 2014; Kossowska-Cezak 2014; Tomczyk 2015a). Znacznie mniej prac dotyczy występowania dni i nocy charakterystycznych w sezonie zimowym (Bielec-Bąkowska i Łupikasza 2009; Kejna i in. 2009; Tomczyk 2015).

W licznych pracach analizuje się występowanie ekstremalnych wartości temperatury powietrza w kontekście ich cyrkulacyjnych uwarunkowań (Ustrnul i in. 2010; Tomczyk i Bednorz 2016; Wibig 2018), ponieważ cyrkulacja atmosferyczna jest jednym z najważniejszych czynników kształtujących warunki pogodowe i klimatyczne w umiarkowanych szerokościach geograficznych (Niedźwiedź 1981; Yarnal 1993). Ważną cechą cyrkulacji atmosferycznej nad Europą jest występowanie układów wysokiego ciśnienia, a w szczególności 
układów blokujących cyrkulację strefową (Bielec-Bąkowska 2010; Porębska i Zdunek 2013). W ostatnich dekadach zauważa się wyraźny wzrost częstości układów blokujących nad Europą i równoczesny spadek liczby układów niskiego ciśnienia na południe od $55^{\circ} \mathrm{N}$ (Leckebusch i Ulbrich 2004; Leckebusch i in. 2008; Bielec-Bąkowska 2014). Jak wykazali Kyselý i Domonkos (2006), coraz częstsze występowanie ekstremalnych wartości temperatury powietrza w Europie może być związane ze wzrostem stałości antycyklonalnych typów cyrkulacji atmosferycznej.

Mając na uwadze obserwowane ocieplenie klimatu, zasadne jest przyjęcie za cel badań:

1) określenie wieloletniej zmienności w występowaniu nocy mroźnych w Poznaniu w latach 1966/67-2015/16,

2) określenie sytuacji barycznych oraz typów cyrkulacji sprzyjających występowaniu nocy mroźnych w Poznaniu w badanym wieloleciu.

\section{DANE I METODY BADAŃ}

Niniejsza praca została zrealizowana na podstawie dobowych wartości minimalnej temperatury powietrza $\left(T_{\min }\right)$ na stacji meteorologicznej zlokalizowanej w Poznaniu z lat 1966-2016 (ryc. 1). Dane pozyskano z Instytutu Meteorologii i Gospodarki Wodnej - Państwowego Instytutu Badawczego.

W pracy za noc mroźną przyjęto dobę, w której minimalna temperatura powietrza była niższa niż $-10^{\circ} \mathrm{C}$. Powyższa definicja została wcześniej użyta przez Kudzewicza i Huanga (2010).

Na podstawie danych wyliczono średnią $\mathrm{T}_{\min } \mathrm{W}$ poszczególnych sezonach zimowych, a następnie wyznaczono noce mroźne. Zmiany sezonowej $\mathrm{T}_{\min }$ oceniono przy użyciu regresji liniowej, a istotność trendów sprawdzono testem t-Studenta. Z kolei do oceny tendencji zmian liczby nocy mroźnych wykorzystano nieparametryczny test Mann-Kendalla.

Następnie określono wpływ Oscylacji Północnoatlantyckiej (NAO) na występowanie nocy mroźnych. W tym celu wyliczono współczynnik korelacji Pearsona między liczbą nocy mroźnych a wartością indeksu NAO. Współczynnik korelacji wyliczono dla poszczególnych miesięcy sezonu zimowego oraz całego sezonu. Oscylacja Północnoatlantycka jest to dwubiegunowy typ cyrkulacji będący wynikiem współdziałania Wyżu Azorskiego i Niżu Islandzkiego. Pozytywna faza NAO wiąże się z niższym niż przeciętnie ciśnieniem w centrum Niżu Islandzkiego i wyższym w Wyżu Azorskim. Konsekwencją tego jest duży gradient ciśnienia, powodujący adwekcję wilgotnych i ciepłych mas powietrza nad północną część kontynentu z zachodu. Z kolei współwystępowanie wyższego od średniej wartości ciśnienia w Niżu Islandzkim i niższego w Wyżu Azorskim stanowi ujemną fazę NAO, która generuje napływ suchych i chłodnych mas 


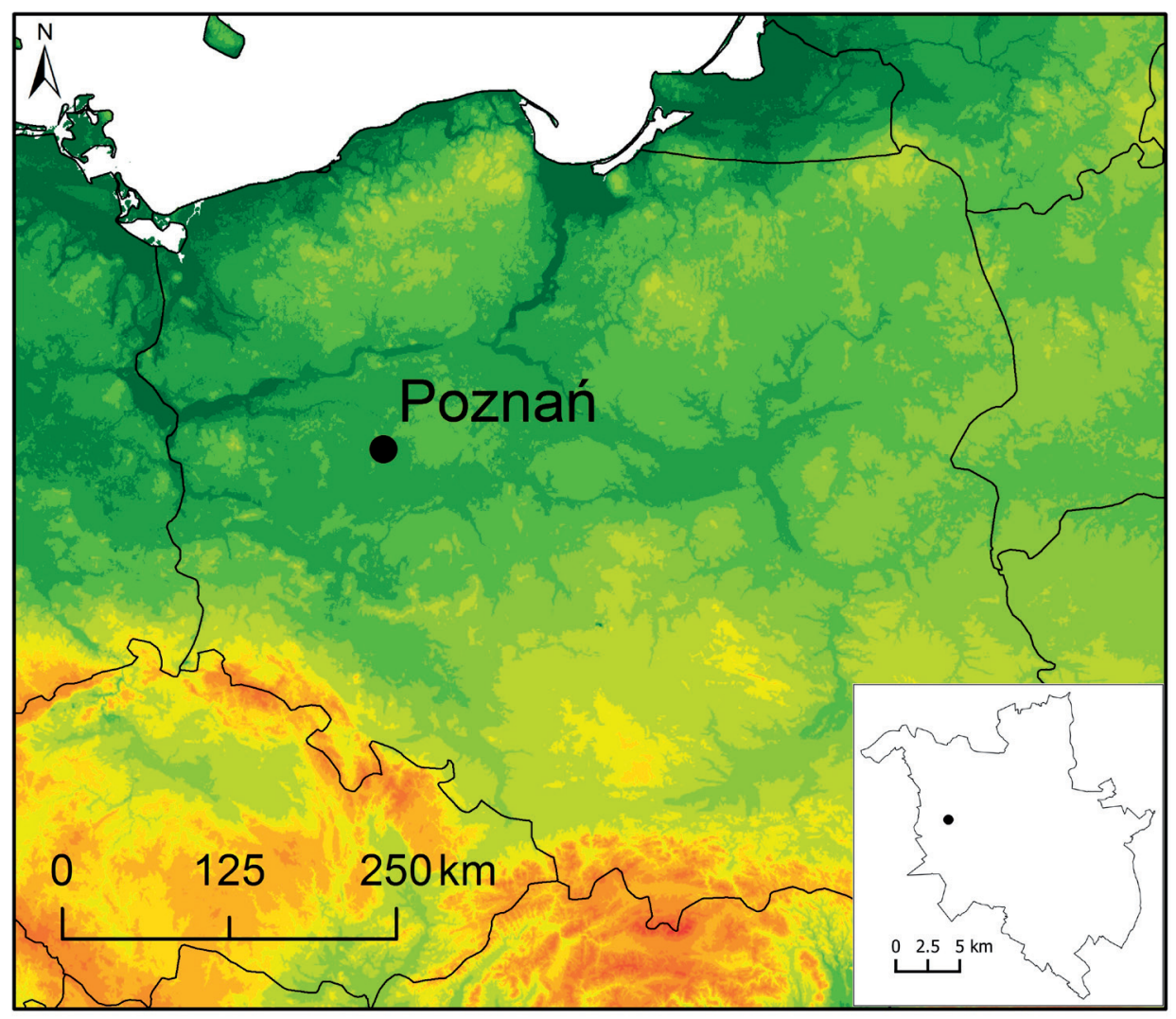

Ryc. 1. Lokalizacja stacji meteorologicznej (czarny punkt)

Fig. 1. Location of meteorological stations (black point)

powietrza z północnego wschodu nad środkową Europę (Hurrell 1995; Hurrell i Deser 2010). Jak wykazano w wielu publikacjach, NAO jest makroskalowym typem cyrkulacji najsilniej oddziałującym na warunki termiczne i śnieżne w środkowej Europie (Bednorz 2009; Tomczyk 2015; Ptak i in. 2018) spośród czterech makroskalowych typów cyrkulacji w sektorze Euroatlantyckim wydzielonych przez Barnston i Livezey (1987). Wartości indeksu NAO pozyskano z baz danych Climate Prediction Center (CPC) NOAA (lata 1966-2015).

W celu określenia warunków barycznych i termicznych występujących podczas nocy mroźnych wykorzystano dobowe wartości ciśnienia atmosferycznego na poziomie morza, następujące wysokości powierzchni izobarycznych: $1000,925,850,700,600,500,400,300,250,200,150,70 \mathrm{hPa}$ oraz temperaturę powietrza na wymienionych poziomach. Dane dla punktów węzłowych siatki geograficznej $2,5 \times 2,5$ dla obszaru $25-75^{\circ} \mathrm{N}$ i $35^{\circ} \mathrm{W}-65^{\circ} \mathrm{E}$ wykorzystano ze zbiorów National Center for Environmental Prediction/National Center for 
Atmospheric Research (NCEP/NCAR) Reanalysis (Kalnay i in. 1996) dostępnych w archiwach NOAA ESRL PSD (Earth System Research Laboratory Physical Science Division).

W pierwszej kolejności, na podstawie powyższych danych, wykreślono przekroje przez troposferę (od poziomu $1000 \mathrm{hPa}$ do poziomu $70 \mathrm{hPa}$ ) z anomaliami wysokości geopotencjałów i temperatury powietrza wzdłuż południka $15^{\circ} \mathrm{E}$ i równoleżnika $52,5^{\circ} \mathrm{N}$. Następnie wykreślono średnie mapy ciśnienia na poziomie morza (SLP) i wysokości powierzchni izobarycznej $300 \mathrm{hPa}$ (z300 hPa) oraz mapy anomalii powyższych parametrów i temperatury powietrza na powierzchni izobarycznej $850 \mathrm{hPa}$ (T850) podczas wszystkich wyznaczonych nocy mroźnych. Wyboru poziomu $300 \mathrm{hPa}$ dokonano na podstawie największych wartości anomalii wysokości geopotencjałów przedstawionych na przekrojach przez troposferę. Ponadto poziom $300 \mathrm{hPa}$ jest powszechnie wykorzystywany w synoptyce. Wszystkie anomalie wyliczono jako różnicę pomiędzy średnią wartością ciśnienia na poziomie morza w konkretnym dniu, wysokością powierzchni izobarycznych i temperaturą powietrza na tych poziomach a średnią wartością powyższych elementów w danym dniu w badanym wieloleciu.

W celu dokładniejszego zbadania warunków cyrkulacyjnych sprzyjających występowaniu nocy mroźnych wydzielono typy cyrkulacji, a następnie wykreślono dla nich mapy analizowanych parametrów. Wydzielenia typów cyrkulacji dokonano przez grupowanie poszczególnych nocy mroźnych pod względem wartości ciśnienia na poziomie morza, stosując metodę minimalnych wariancji, znaną jako metoda Warda (1963). Metoda ta opiera się na odległościach euklidesowych. Jej istotą jest łączenie dwóch skupień A i B, które po połączeniu w jedno skupienie zapewniają minimum sumy kwadratów odchyleń wszystkich obiektów od środka ciężkości nowo utworzonego skupienia (Ward 1963; Bednorz 2009). W tym celu wykorzystano standaryzowane wartości SLP. Standaryzacji dokonano, aby wyrównać sezonową zmienność z zachowaniu intensywności pola ciśnienia (Esteban i in. 2005). Metody grupowania, m.in. metoda Warda, często znajdują zastosowanie w klimatologii, np. przy wydzielaniu sezonów i regionów klimatycznych oraz wyróżnianiu typów pogody (Bednorz 2009; Tomczyk i Bednorz 2014).

\section{WYNIKI}

Średnia $\mathrm{T}_{\min }$ zimą (grudzień-luty) w latach 1966/67-2015/16 w Poznaniu wynosiła $-2,9^{\circ} \mathrm{C}$. Najniższą średnią $\mathrm{T}_{\min }\left(-9,3^{\circ} \mathrm{C}\right)$ odnotowano w sezonie $1969 / 70$ (ryc. 2). Równie zimne sezony wystąpiły w latach: 1984/85, 1995/96, 1978/79, 1968/69 oraz 2002/03. Z kolei najwyższą średnią $\mathrm{T}_{\text {min }}$ odnotowano w sezonie $2006 / 07$, wynosiła aż $1,1^{\circ} \mathrm{C}$. Ponadto ciepłe zimy, ze średnią znacznie powyżej 
$0^{\circ} \mathrm{C}$, wystąpiły w latach: 1988/89, 2015/16, 1989/90 i 2007/08. Odchylenie standardowe dla danego wielolecia wynosiło $2,3^{\circ} \mathrm{C}$. W badanym latach stwierdzono tendencję rosnącą $\mathrm{T}_{\min }$ na poziomie $0,40^{\circ} \mathrm{C} / 10$ lat, aczkolwiek zmiany te nie były istotne statystycznie.

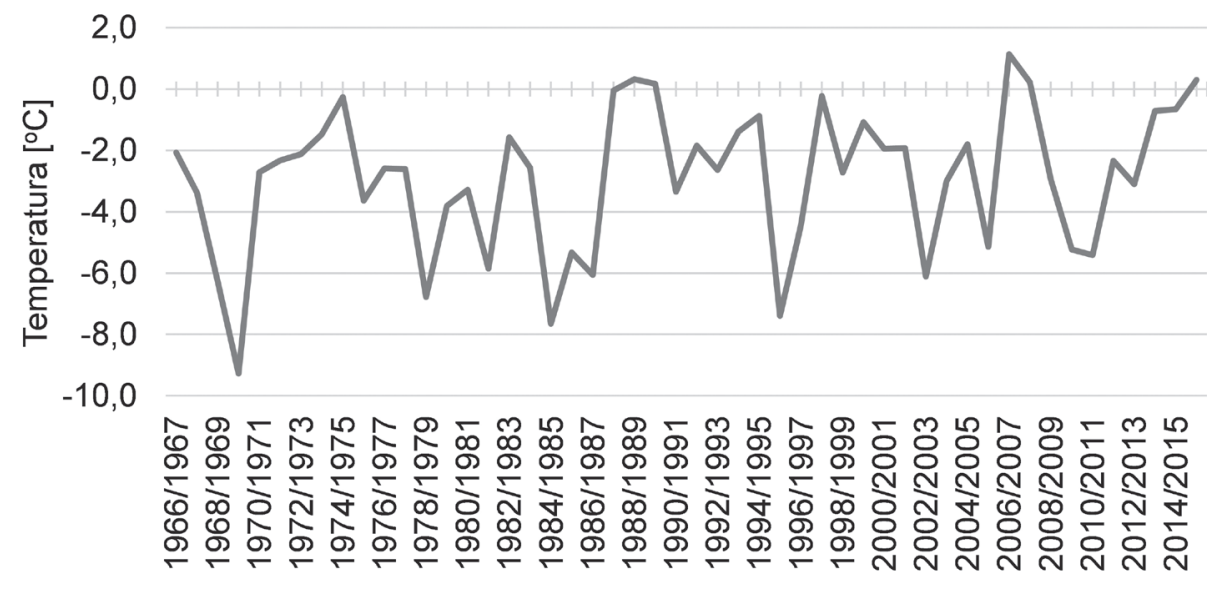

Ryc. 2. Średnia minimalna temperatura powietrza w sezonie zimowym w Poznaniu w latach 1966/67-2015/16

Fig. 2. Average minimum air temperature in the winter season in Poznań in the years $1966 / 67-2015 / 16$

W latach 1966/67-2015/16 w Poznaniu w trakcie każdego sezonu zimowego przeciętnie notowano 10 nocy mroźnych. W poszczególnych sezonach ich liczba była zróżnicowana, o czym świadczy wartość odchylenia standardowego, która wynosiła 9,2 dnia. Tylko podczas trzech sezonów (1988/89, 1994/95, 2007/08) nie odnotowano ani jednej nocy mroźnej (ryc. 3A). Z kolei ich maksymalna liczba wynosiła 36 i była odnotowana zimą 1969/70. W ujęciu miesięcznym noce mroźne najczęściej występowały w styczniu, stanowiły 44,5\% wszystkich odnotowanych przypadków. W badanym wieloleciu stwierdzono tendencję spadkową sezonowej liczby nocy mroźnych na poziomie $0,8 \mathrm{dni} / 10$ lat, aczkolwiek powyższe zmiany nie były istotne statystycznie. W zdecydowanej większości sezonów zimowych noce mroźne najczęściej występowały jako pojedyncze przypadku lub ciągi dwóch nocy, które w trakcie sześciu sezonów stanowiły poniżej 50\% wszystkich nocy mroźnych (ryc. 3B). Najdłuższy ciąg nocy mroźnych odnotowano w 2011 r. od 30 stycznia do 12 lutego.

W badanym okresie Oscylacja Północnoatlantycka istotnie statystycznie wpływała na występowanie nocy mroźnych. Korelacja miała znak ujemny, a więc negatywnej fazie NAO towarzyszył wzrost częstości nocy z temperaturą poniżej $-10^{\circ} \mathrm{C}$. Najsilniejszy związek Oscylacji Północnoatlantyckiej 


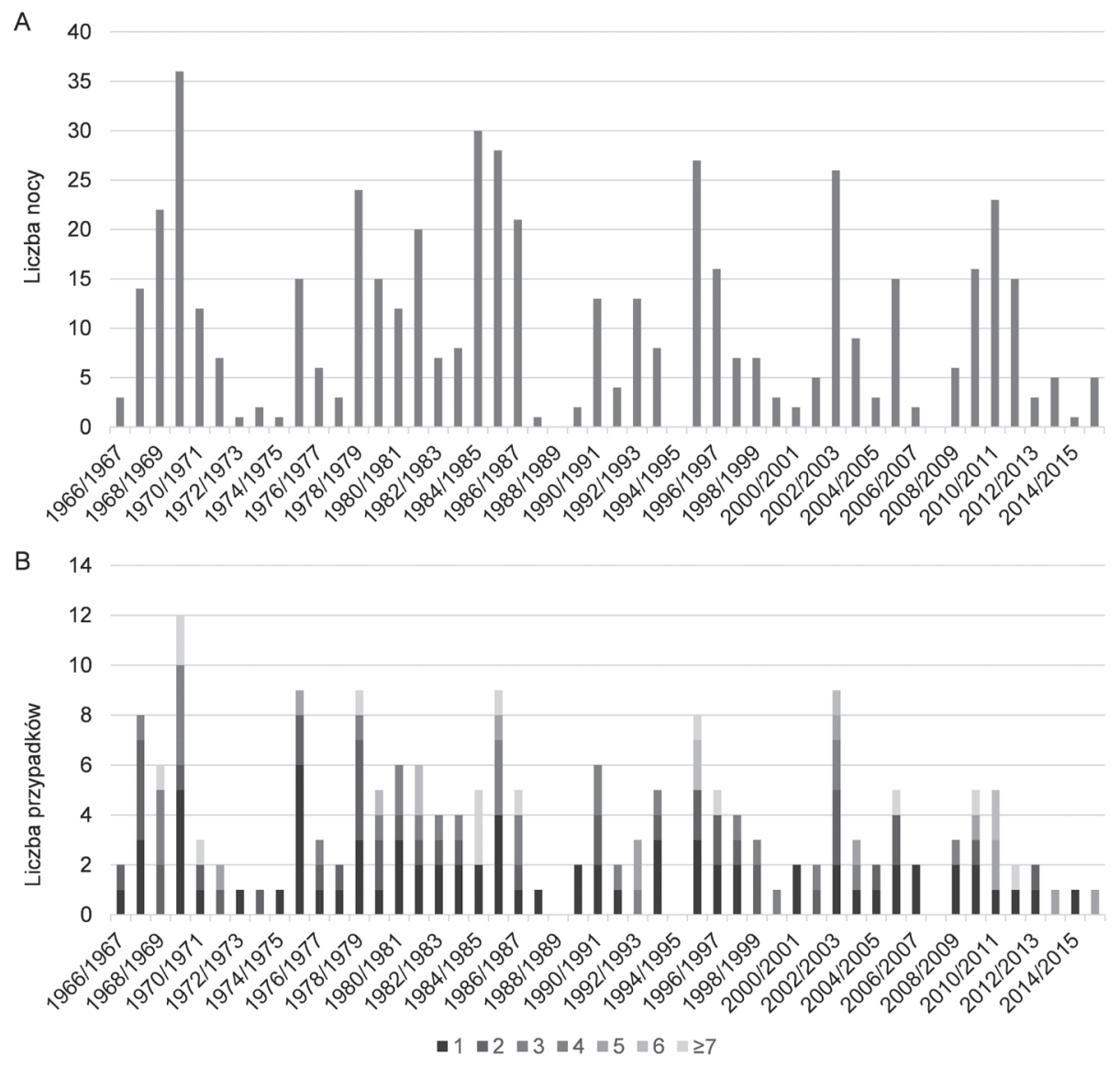

Ryc. 3. Liczba nocy mroźnych (A) oraz liczba ciągów (B) nocy mroźnych w Poznaniu w latach 1966/67-2015/16

Fig. 3. Number of frosty nights (A) and number of sequences (B) of frosty nights in Poznań in $1966 / 67-2015 / 16$

z miesięczną liczbą nocy mroźnych stwierdzono w styczniu $(r-0,66)$. Słabszą korelację odnotowano $\mathrm{w}$ grudniu $(r-0,57)$ oraz lutym $(r-0,27)$. Z kolei korelacja między zimowym indeksem NAO a sezonową liczbą nocy mroźnych wynosiła $-0,54$.

W trakcie analizowanych nocy mroźnych notowano niższe zaleganie poziomów izobarycznych aniżeli średnio w danych dniach w rozpatrywanym wieloleciu. Największe ujemne anomalie wysokości geopotencjałów notowano na poziomach $300-250 \mathrm{hPa}$, które przekraczały $110 \mathrm{~m}$ wzdłuż południka $15^{\circ} \mathrm{E}$ (ryc. 4A). Centrum anomalii było przesunięte na południe względem analizowanego obszaru. W słupie powietrza poniżej centrum ujemnych anomalii geopotencjałów, z niewielkim przesunięciem na północ, notowano ujemne 


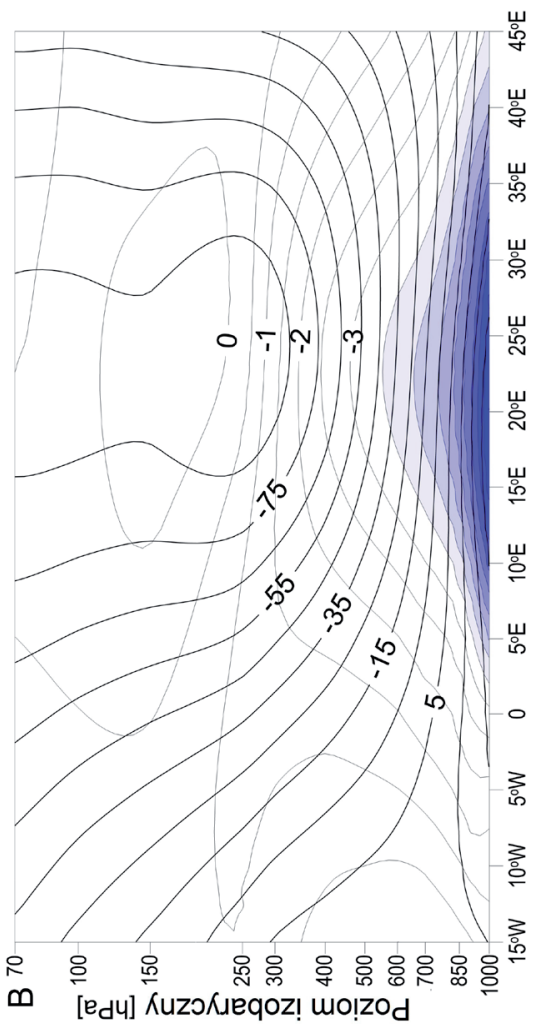

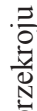

它

ప. तี

$3 \quad \cdot \frac{0}{0} \cdot \frac{0}{0}$

苛 专

Nㅡㄴ $\Xi$

리용

¿

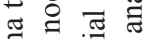

규 를

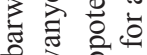

군

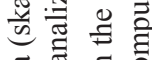

กี

.

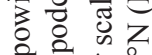

를

릉 응

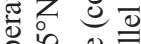

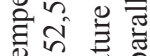

.

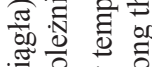

일 을

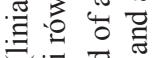

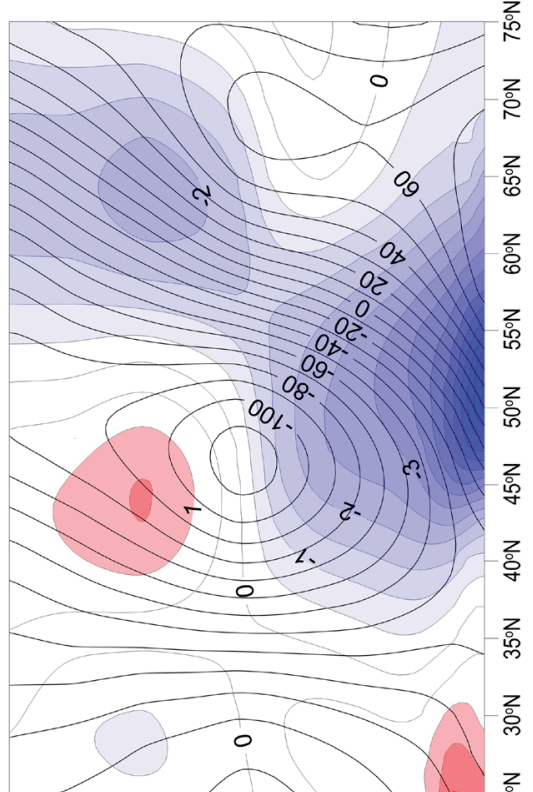

류 률

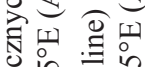

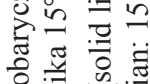

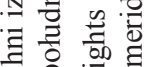

仓

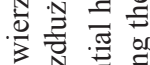

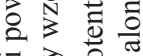

- गे क्षे

光

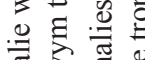

咅

ส․ํำ

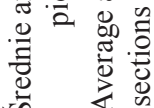

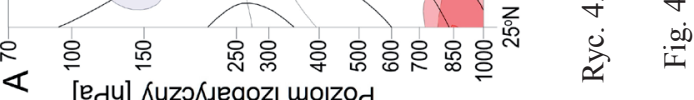


anomalie temperatury powietrza, którymi objęty był przeważający obszar kontynentu. Największe anomalie temperatury powietrza notowano na najniższych poziomach izobarycznych, $1000-850 \mathrm{hPa}$, gdzie maksymalnie wynosiły poniżej $-7^{\circ} \mathrm{C}$. Z kolei w górnej troposferze (powyżej poziomu $250 \mathrm{hPa}$ ) notowano dodatnie anomalie temperatury powietrza. Taki rozkład anomalii temperatury powietrza był spowodowany ruchem mas powietrza w układzie antycyklonalnym utworzonym nad środkową Europą.

Występowanie nocy mroźnych w Poznaniu przeciętnie było związane z zaleganiem nad przeważającym obszarem Europy klina wysokiego ciśnienia, w obrębie którego wykształcił się lokalny wyż. W centrum układu, położonym nad środkową Europą, SLP wynosiło powyżej $1022 \mathrm{hPa}$ (ryc. 5A). W analizowanych dniach obszar badań znajdował się w zasięgu dodatnich anomalii SLP, które wynosiły około $5 \mathrm{hPa}$ (ryc. 5B). Jednocześnie nad Oceanem Atlantyckim zalegał płytszy Niż Islandzki i słabszy Wyż Azorski, co wskazuje na ujemną fazę NAO. Nad Morzem Śródziemnym zalegał układ niskiego ciśnienia, w centrum którego SLP wynosiło poniżej $1013 \mathrm{hPa}$. Izohipsy powierzchni izobarycznej $300 \mathrm{hPa}$ nad Oceanem Atlantyckim i zachodnią Europą wygięte były ku północy, a nad środkową i wschodnią Europą ku południowi. Nad przeważającym obszarem kontynentu z300 hPa zalegała niżej niż przeciętnie, a w centrum układu anomalie wynosiły poniżej poniżej $-100 \mathrm{~m}$. Wskazuje to na zaleganie chłodnych mas powietrza, co potwierdzają również anomalie T850 (ryc. 5C). W rozpatrywanych dniach centrum anomalii T850 zalegało nad południowo-wschodnią Polską, gdzie temperatura była niższa niż przeciętnie poniżej $-5^{\circ} \mathrm{C}$. Przebieg izoanomalii wskazuje na adwekcję kontynentalnych mas powietrza z północnego wschodu nad środkową Europę.

Ze szczegółowych badań cyrkulacji atmosferycznej wynika, że występowanie nocy mroźnych w Poznaniu było związane z dwoma sytuacjami barycznymi (ryc. 6). W typie 1 nad środkową Europą zalegał układ wysokiego ciśnienia $\mathrm{z}$ centrum nad południową Polską ( $>1023 \mathrm{hPa}$ ). Z kolei północna Europa pozostawała pod wpływem niżu z centrum nad Morzem Barentsa $(<1002 \mathrm{hPa})$. Także nad Oceanem Atlantyckim zalegał układ niskiego ciśnienia z centrum na południowy zachód od Islandii $(<1004 \mathrm{hPa})$. Oba układy tworzyły rozległy obszar obniżonego ciśnienia rozciągający się od Morza Barentsa przez północną Europę po Ocean Atlantycki. Z kolei w typie 2 obszar środkowej Europy pozostawał pod wpływem wyżu z centrum nad północno-zachodnią Rosją (> $1029 \mathrm{hPa})$. Jednocześnie nad zachodnią i południową Europą zalegała zatoka niskiego ciśnienia, w obrębie której wykształcił się lokalny niż nad Korsyką i Sardynią $(<1011 \mathrm{hPa})$. W przypadku obu typów obszar badań znajdował się w zasięgu dodatnich anomalii SLP. W typie 1 centrum układu anomalii zalegało nad Oceanem Atlantyckim, na północ od Wysp Brytyjskich ( $>10 \mathrm{hPa}$ ), a w typie 2 nad Finlandią i Zatoką Botnicką (> $18 \mathrm{hPa}$ ). Opisane układy baryczne powodowały adwekcję chłodnych mas powietrza. Wskazuje na to przebieg 


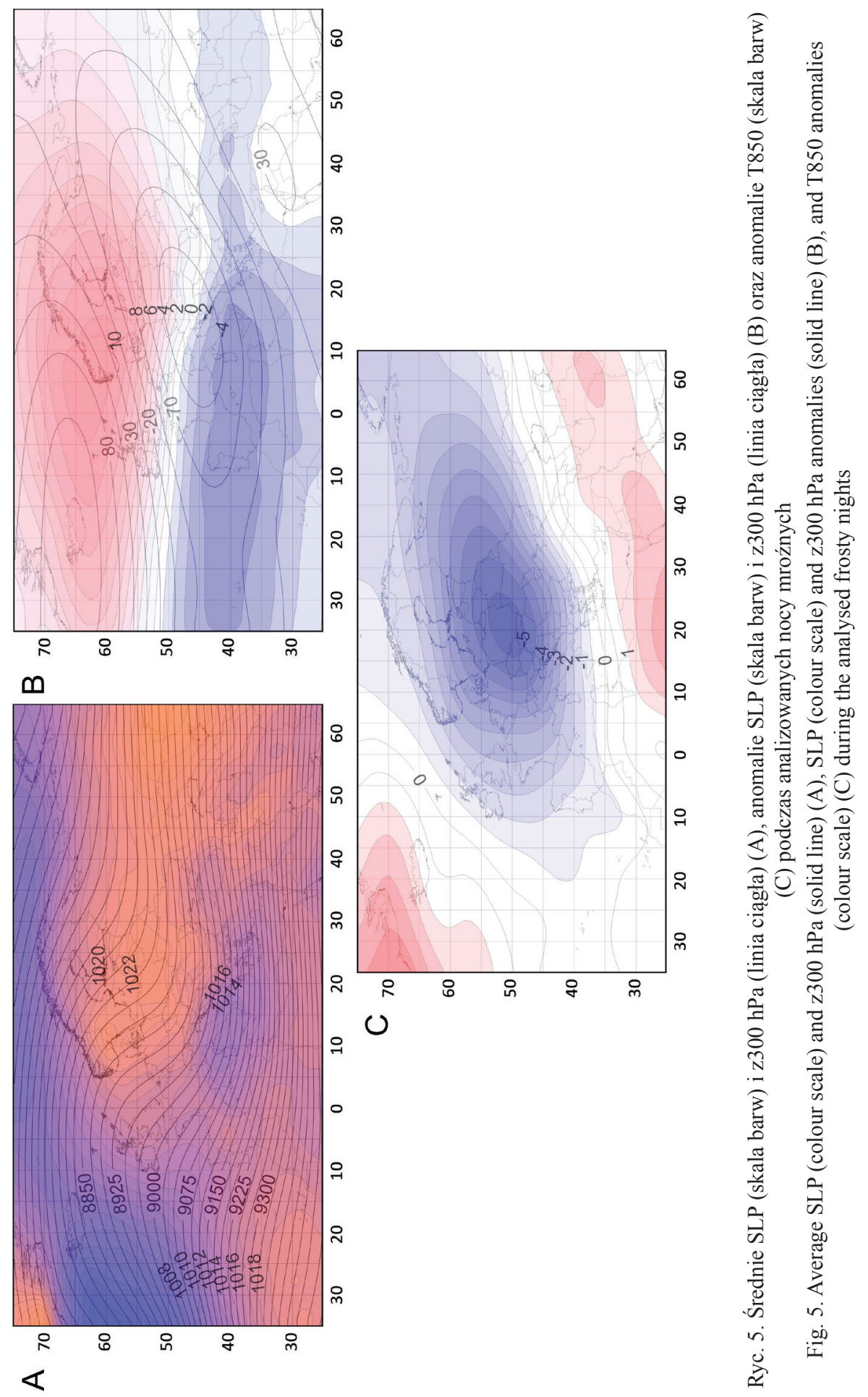



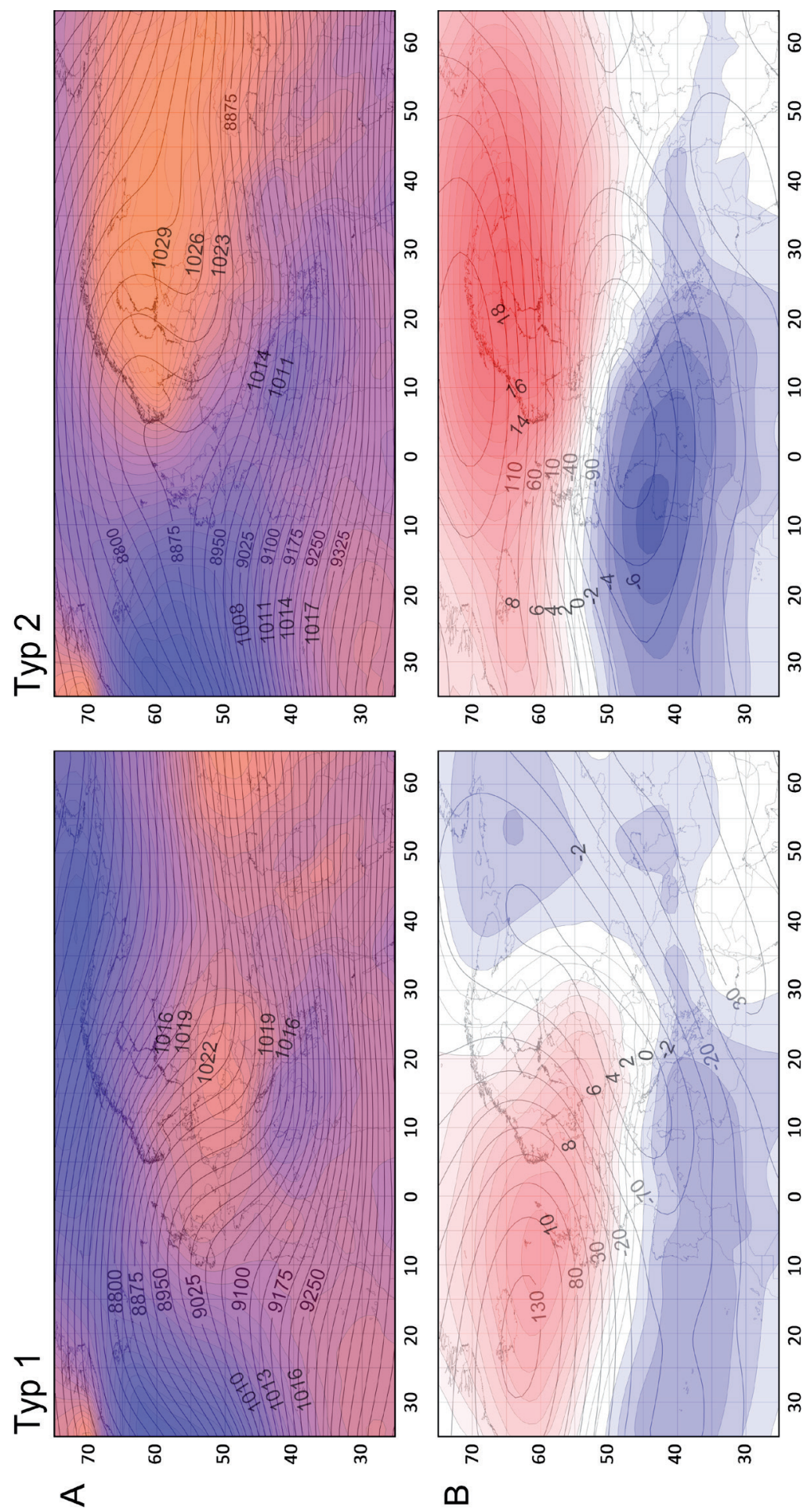

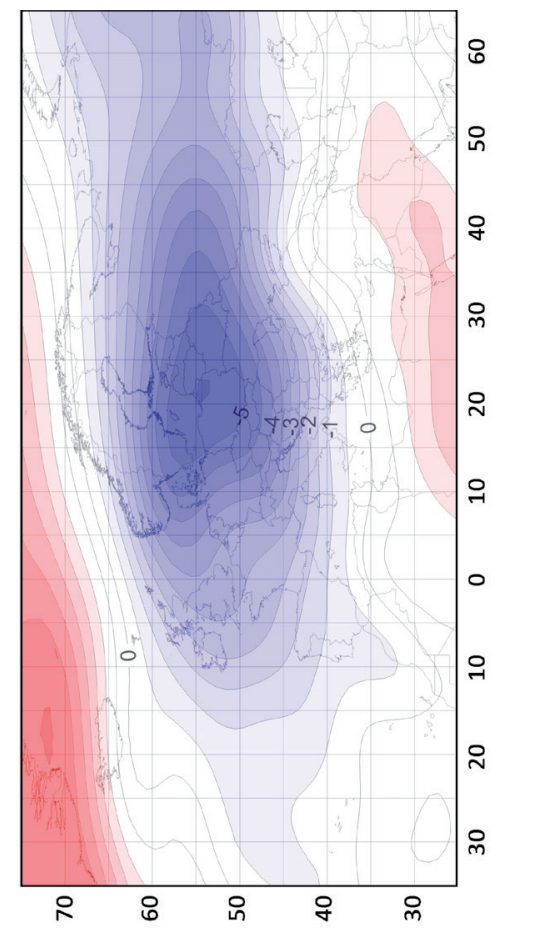

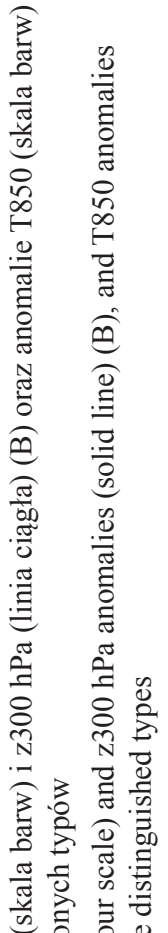

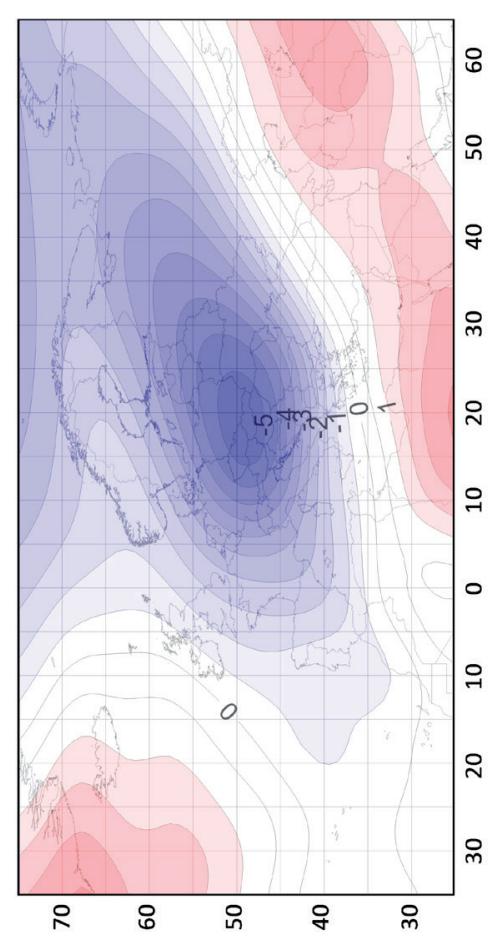

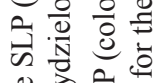

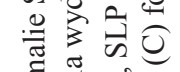

i $\quad$ 言

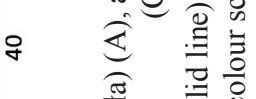

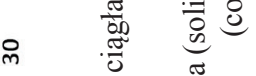

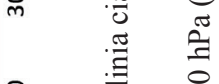

ก

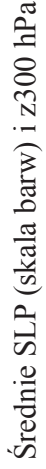

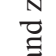

$\frac{\pi}{\frac{\pi}{\pi}}$

0

ن 
izohips powierzchni izobarycznych $300 \mathrm{hPa}$, które nad środkową Europą były wygięte ku południu i południowemu zachodowi, tworzą jej wyraźne obniżenie nad tą częścią kontynentu. Potwierdzają to również ujemne anomalie z300 hPa. Przebieg izoanomalii T850 wskazuje na adwekcję mas powietrza z północnego wschodu w typie 1, a ze wschodu w typie 2 .

\section{DYSKUSJA I PODSUMOWANIE}

$\mathrm{W}$ badanych latach stwierdzono tendencję wzrostową $\mathrm{T}_{\min } \mathrm{W}$ sezonie zimowym w Poznaniu, aczkolwiek odnotowane zmiany nie były istotne statystycznie. Podobny kierunek zmian $\mathrm{T}_{\min }$ na obszarze Polski wykazali Owczarek i Filipiak (2016).

Konsekwencją obserwowanego ocieplenia jest spadek liczby nocy mroźnych w Poznaniu. Podobnie jak w przypadku zmian $\mathrm{T}_{\min }$ stwierdzone zmiany nie były istotne statystycznie. We wcześniejszych badaniach wielokrotnie wskazywano na spadek liczby dni mroźnych i fal mrozów jako przejaw obserwowanego ocieplenia (Wibig i in. 2009; Tomczyk 2015b; Owczarek i Filipiak 2016; Tomczyk 2016).

Występowanie nocy mroźnych w Poznaniu było związane średnio z obecnością układu wyżowego nad środkową Europą, który wykształcił się w klinie wysokiego ciśnienia rozciągającego się nad przeważającym obszarem kontynentu. $\mathrm{W}$ rozpatrywanych dniach ciśnienie było wyższe niż przeciętnie w analizowanym wieloleciu. Taki układ baryczny zapewniał adwekcję chłodnych, kontynentalnych mas powietrza. Porębska i Zdunek (2013) wskazywały na występowanie anomalii temperatury powietrza przy układach wysokiego ciśnienia, blokujących cyrkulację strefową. Z kolei Ustrnul i in. (2010) dowiedli, że występowanie niskich wartości temperatury w Polsce wiąże się z sytuacją antycyklonalną $\mathrm{z}$ adwekcją mas powietrza $\mathrm{z}$ sektora wschodniego.

Ze szczegółowych badań wynika, że występowanie nocy mroźnych było związane z dwoma typami cyrkulacji atmosferycznej. Zarówno w typie 1, jak i 2 obszar badań znajdował się pod wpływem układu wysokiego ciśnienia, powodującego adwekcję chłodnych mas powietrza, ale także zapewniających silne wypromieniowanie ciepła przy niewielkim zachmurzeniu bądź jego braku. Podobne warunki baryczne sprzyjały występowaniu fal mrozów (Tomczyk i Bednorz 2014; Tomczyk 2016), w trakcie których z reguły obszar badań objęty był dodatnimi anomaliami SLP oraz ujemnymi anomaliami z500 hPa. Opisane układy baryczne powodowały adwekcję chłodnych mas powietrza.

Praca została częściowo sfinansowana ze środków Narodowego Centrum Nauki przyznanych na podstawie umowy: UMO-2017/24/C/ST10/00109. 


\section{LITERATURA}

Barnston A.G., Livezey R.E., 1987: Classification, seasonality and persistence of low-frequency atmospheric circulation patterns, Monthly Weather Rev., 115, 1083-1126.

Bartoszek K., Węgrzyn A., Sienkiewicz E., 2014: Częstość występowania i uwarunkowania cyrkulacyjne nocy cieptych, bardzo ciepłych oraz goracych w okolicach Lublina i Nałęczowa, Przegl. Nauk. Inż. i Kształtowanie Środ., 66, 410-420.

Bednorz E., 2009: Wpływ sytuacji barycznych na występowanie pokrywy śnieżnej na obszarach nizinnych środkowej Europy, Wyd. Nauk. UAM, Poznań.

Bielec-Bąkowska Z., 2010: Silne wyże nad Europa w XX wieku, [w:] L. Kolendowicz (red.), Klimat Polski na tle klimatu Europy. Warunki cyrkulacyjne i radiacyjne, Bogucki Wyd. Nauk. Poznań, 23-37.

Bielec-Bąkowska Z., 2014: Silne wyże nad Europa (1951-2010), Wyd. UŚ, Katowice.

Bielec-Bąkowska Z., Łupikasza E., 2009: Frosty, freezing and severe freezing days and their synoptic implications in Małopolska, Southern Poland, 1951-2000, Bull. of Geogr. - Phys. Geogr., 1, 35-56.

Esteban P., Jones P.D., Martin-Vide J., Mases M., 2005: Atmospheric circulation patterns related to heavy snowfall days in Andorra, Pyrenees, Internat. Journ. of Clim., 25, 319-329.

Hoy A., Hänsel S., Skalak P., Ustrnul Z., Bochníček O., 2017: The extreme European summer of 2015 in a long-term perspective, Internat. Journ. of Clim., 37, 2, 943-962.

Hurrel J.W., 1995: Decadal trends in the North Atlantic oscillation: regional temperatures and precipitation, Sc., 269, 676-679.

Hurrel J.W., Deser C., 2010: North Atlantic climate variability: the role of the North Atlantic Oscillation, Journ. of Marine Systems, 78, 28-41.

Kalnay E., Kanamistu M., Kistler R., Collins W., Deaven D., Gandin L., Iredell M., Saha S., White G., Woollen J., Zhu Y., Leetmaa A., Reynolds R., Chelliah M., Ebisuzaki W., Higgins W., Janowiak J., Mo K.C., Ropelewski C., Wang J., Jenne R., Joseph D., 1996: The NMC/NCAR 40-Year Reanalysis Project, Bull. of the Amer. Meteor. Soc., 77, 437-471.

Kejna M., Araźny A., Maszewski R., Przybylak R., Uscka-Kowalowska J., Vizi Z., 2009: Daily minimum and maximum air temperature in Poland in the years 1951-2005, Bull. of Geogr. Phys. Geogr., 2, 35-56.

Kossowska-Cezak U., 2014: Zmiany wieloletnie liczby termicznych dni charakterystycznych $w$ Warszawie (1951-2010), Pr. Geogr., 136, 9-30.

Krzyżewska A., 2015: Szczególnie ucią̇liwe fale upatów w Lublinie, Przegl. Geofiz., 60, 3-4, $207-215$.

Kundzewicz Z.W., Huang S., 2010: Seasonal temperature extremes in Potsdam, Act. Geophys. $58,6,1115-1133$.

Kyselý J., Domonkos P., 2006: Recent increase in persistence of atmospheric circulation over Europe: comparison with long-term variations since 1881, Internat. Journ. of Clim., 26, 461-483.

Leckebusch G.C., Ulbrich U., 2004: On the relationship between cyclones and extreme windstorms over Europe under climate change, Global Planet Change, 44, 181-193.

Leckebusch G.C., Weimer A., Pinto J.G., Reyers M., Speth P., 2008: Extreme wind storms over Europe in present and future climate: a cluster analysis approach, Meteor. Zeitschr., 17, 67-82.

Matuszko D., Piotrowicz K., 2012: Wieloletnia zmienność sytuacji meteorotropowych w Krakowie, Przegl. Geogr., 84(3), 413-422.

Michalska B., 2011: Tendencje zmian temperatury powietrza w Polsce, Pr. i Stud. Geogr., 47, $67-75$.

Niedźwiedź T., 1981: Sytuacje synoptyczne i ich wpływ na zróżnicowanie przestrzenne wybranych elementów klimatu $w$ dorzeczu górnej Wisty, Rozprawy Habilitacyjne Uniwersytetu Jagiellońskiego 58, Kraków. 
Owczarek M., Filipiak J., 2016: Contemporary changes of thermal conditions in Poland, 19512015, Bull. of Geogr. - Phys. Geogr. Ser. 10, 31-50.

Porębska M., Zdunek M., 2013: Analysis of extreme temperature events in Central Europe related to high pressure blocking situations in 2001-2011, Meteor. Zeitschr., 22, 5, 533-540.

Półrolniczak M., Tomczyk A.M., Kolendowicz L., 2018: Thermal Conditions in the City of Poznań (Poland) during Selected Heat Waves, Atmosphere, 2, 9, 11.

Ptak M., Tomczyk A.M., Wrzesiński D., 2018: Effect of teleconnection patterns on changes in water temperature in Polish lakes, Atmosphere, 9, 66, 1-17.

Shevchenko O., Lee H., Snizhko S., Mayer H., 2014: Long-term analysis of heat waves in Ukraine, Internat. Journ. of Clim., 34, 1642-1650.

Tomczyk A.M., 2015a: Very warm nights in Polish coastal area of the Baltic Sea, Geogr. Polon., $88,3,493-502$.

Tomczyk A.M., 2015b: Impact of macro-scale circulation types on the occurrence of frosty days in Poland, Bull. of Geogr. - Phys. Geogr. Ser. 9. 55-65.

Tomczyk A.M., 2016: Fale mrozów w Poznaniu i ich cyrkulacyjne uwarunkowania, Bad. Fizjograf., Ser. A. Geogr. Fiz. 67, PTPN, Poznań, 257-269.

Tomczyk A.M., Bednorz E., 2014: Heat and cold waves on the southern coast of the Baltic Sea, Baltica, 27(1), 45-53.

Tomczyk A.M., Bednorz E., 2016: Heat waves in Central Europe and their circulation conditions, Internat. Journ.of Clim., 36, 2, 770-782.

Ustrnul Z., Czekierda D., Wypych A., 2010: Extreme values of air temperature in Poland according to different atmospheric circulation classifications, Phys. and Chem. of the Earth, 35, 429-436.

Ward J.H., 1963: Hierarchical grouping to optimize an objective function, Journ. of the Amer. Statist. Ass., 58, 236-244.

Wibig J., 2018: Heat waves in Poland in the period 1951-2015: trends, patterns and driving factors, Meteor. Hydrol. and Water Management, 6, 1, 37-45.

Wibig J., Podstawczyńska A., Rzepa M., Piotrowski P., 2009: Coldwaves in Poland-Frequency, trends and relationships with atmospheric circulation, Geogr. Polon., 82, 47-59.

Wójcik R., Miętus M., 2014: Niektóre cechy wieloletniej zmienności temperatury powietrza w Polsce (1951-2010), Przegl. Geogr., 86, 3, 339-364.

Yarnal B., 1993: Synoptic Climatology in Environmental Analysis, Belhaven Press, London. 